\title{
Penanaman Karakter Religius Melalui Metode Pembiasaan
}

\author{
Siswanto ${ }^{1}$, Ifnaldi Nurmal ${ }^{2}$, Syihab Budin ${ }^{3}$ \\ ${ }^{12}$ Institut Agama Islam Negeri Curup, \\ ${ }^{3}$ Institut Agama Islam Negeri Kudus \\ 1sis66505@gmail.com, ${ }^{2}$ ifnaldi@gmail.com, \\ 3syhabbudin56@gmail.com
}

\begin{abstract}
This study is to describe how to instill religious character education through habituation methods in the Integrated Islamic Elementary School in Semarak Rejang Lebong. The type of research in qualitative where the approach used is descriptive qualitative. Furthermore, the data obtained by interview, observation and documentation. Furthermore, the analysis is carried out by data reduction, data display, and drawing conclusions. Furthermore, the study resulted that the cultivation of religious character education carried out in an integrated Islamic elementary school in Serak Rejang Lebong through the habituation method was carried out by the first way of habituation every day by carrying out the Duha prayer, the second performing the dhuhur prayer in congregation and specifically on Friday and Saturday morning children. -Children gather in the field to carry out murojaah and continue short letters in the Qur'an.
\end{abstract}

Keywords: Religious Character Cultivation, Habitual Method

Abstrak: Penelitian ini untuk mendeskripsikan bagaimana cara penanaman pendidikan karakter religius melalui metode pembiasaan yang ada di Sekolah Dasar Islam Terpadu di Semarak Rejang Lebong. Adapun jenis penelitian in kualitatif dimana pendekatan yang digunakan dengan deskriptif kualitatif. Selanjutnya data diperoleh dengan wawancara, observasi serta dokumentasi. Selanjutnya analisis dilakukan dengan reduksi data, display data, dan penarikan kesimpulan. Selanjutnya penelitian menghasilkan bahwa penanaman pendidikan karakter religius yang dilakukan disekolah dasar Islam terpadu semarak rejang lebong melalui metode pembiasaan deilakukan dengan cara pertama pembiasaan setriap hari dengan melaksanakan shalat dhuha, kedua melakukan shalat dhuhur secara berjamaah dan khusus hari jum'at

AR-RIAYAH : Jurnal Pendidikan Dasar vol. 5, no. 1, 2021

IAIN Curup - Bengkulu l p ISSN 2580-362X; e ISSN 2580-3611

http://journal.iaincurup.ac.id/index.php/JPD

DOI: $10.29240 /$ jpd. v5i1.2627| p. $1-12$ 
dan sabtu pagi anak-anak berkumpul di lapangan untuk melaksanakan murojaah serta sambung surat pendek dalam AlQur'an.

\section{Kata Kunci: Penanaman Karakter Religius, MetodePembiasaan}

\section{PENDAHULUAN}

Proses yang dilakukan secara sadar serta terencana yang dilakukan melalui pembimbingan dan pembelajaran bagi setiap individu agar menjadi seseorang yang mandiri merupakan makna dari pendidikan. Sistem pendidikian nasional menyatakan yaitu pendidikan nasional berfungsi untuk mengembangkan kemampuan untuk mengembangkan kemampuan dan membentuk watak serta peradaban bangsa, bertujuan berkembangnya potensi peserta didik agar menjadi manusia yang beriman, bertakwa kepada tuhan yang maha esa, berahlak mulia, sehat, berilmu, cakap, keratif, mandiri dan menjadi negara yang demoklratis serta bertanggungg jawab.

Pendidikan bagi manusia merupakan suatu yang sangat mutlak dalam hidup ini, kemudian manusia tidak dapat dipisahkan dari kegitan itu. Kegiatan belajar mengajar sebagai salah satu bentuk pembangunan yang di jadikan sebagai sarana kemajuan bangsa. Adapun kualitas manusia pendidikan merupakan sarana dalam meningkatan kualitas manusia dalam segala bidang kehidupan termasuk kehidupan beragama.

Tiga pusat pendidikan merupakan lembaga utama yang sangat berpengaruh dalam perkembangan kepribadian seorang anak. Dimana lingkungan itu adalah lingkungan keluarga, lingkungan sekolah dan lingkungan masyarakat, hal ini juga dijelaskan dalam oleh sebab itu pendidikan merupakan tanggung jawab bersama. Dimana satu bentuk dari pendidikan itu yakni dengan melalui penanaman karakter. Penanaman kerakter perlu ditanamkan sejak dini salah satunya melalui pembiasaan sehari-hari. Lembaga sekolah formal merupakan salah satu sarana efektif dalam pembentukan karakter bagi peserta didiknya, terutama pada murid-muridnya terutama karakter religius.

Penanaman nilai karakter tersebut sangat penting karena anak sekolah dasar. Masa tersebut merupakan masa emas yang harus dibiasakan untuk berprilaku baik. Sebagaimana dikatakan Scerenco bahwa " pendidikan karakter merupakan sebagai upaya yang sungguh-sungguh dengan cara menanamkan ciri kepribadian positif dikembangkan, didorong dan diberdayakan melalui keteladanan, selanjutnya usaha yang maksimal untuk mewujudkan hikmah dari apa-apa yang dipelajari. ${ }^{1}$ Sebagaimana hasil wawancara awal dari salah satu guru di sekolah tersebut mangatakan bahwa "latar belakang anak yang sekolah di sana sangat bermacam-macam dan memiliki kepribadian yang berbeda". Selain itu,dari hasil observasi awal penulis lakukan dari latar belakang pendidikan dan 
keluarga yang bermacam-macam maka menimbulkan kebiasaan beribadah yang berbeda-beda, ada yang sudah rajin dan ada yang masih harus diperintah.

Dari penjelasan di atas, maka penelitian ini penting dilakukan karena sekolah ini masih terbilang baru dan merupakan sekolah dasar Islam terpadu, dimana penanaman nilai karakter religius di sekolah dasar Islam terpadu disemarak rejang lebong setidaknya memberikan dampak yang baik bagi siswa. Maka menjadi menarik untuk diteliti. Apakah strategi penanamna karakter ini diterapkan dengan mngintegrasikan konten pendidikan karakter yang telah dirumuskan ke dalam seluruh mata pelajaran. Atau dengan mengitegrasikan pendidikan karakter ke dalam kegiatan sehari-hari di sekolah melalui pembiasaan.

\section{METODE PENELITIAN}

Teknik analisis data dalam penulisan ini menggunakan analisis deskriptif kualitatif dengan model interaktif (Interactive Model of Analysis) meliputi; pengumpulan data, reduksi data yaitu yaitu memilih hal-hal yang pokok, memfokuskan pada hal-hal yang penting, dicari tema dan polanya dan membuang yang tidak perlu; dan penyajian data, maka penulis akan mudah untuk memahami apa yang terjadi serta merencanakan kerja selanjutnya; terakhir verifikasi yakni pemberian kesimpulan sehingga mendapatkan hasil yang diinginkan. Selanjutnya metode pengumpulan data dengan menggunakan observasi digunakan untuk mengamati proses pembelajaran yang dilakukan disekolah tersebut dimana dilakukan secara bertahap dan pembagian waktu jam masuk, wawancara digunakan untuk memperoleh data yang berkaitan dengan bagaimana cara guru menanamkan nilai karakter religius melalui metode pembiasaan, kemudian data diperoleh dari wali kelas dan guru, selanjutnya dokumentasi untuk memperoleh jadwal yang berkaitan dengan penelitian dan lain-lain. Selanjutnya fokus penelitian disini dilakukan di Sekolah Dasar Islam Terpadu (SD IT) Semarak Rejang Lebong.

\section{HASIL DAN PEMBAHASAN}

\section{Pengertian Karakter}

Watak, tabiat, pembawaan atau kebiasaan merupakan merupakan makna karakter menurut kamus ilmiah populer. ${ }^{3}$ Karakter merupakan cara berfikir dan berperilaku yang menjadi ciri has tiap individu untuk hidup dan bekerja sama, baik dalam lingkup keluarga, masyarakat, bangsa dan negara. Hal ini juga dikemukakan oleh Simon Philips dalam Masnur bahwa karakter merupakan kumpulan tata nilai yang menuju pada suatu sistem yang melandasi suatu pemikiran, sikap, dan perilaku yang ditampilkan. ${ }^{4}$

3 Achmad Maulana dkk, Kamus Imiab Populer (Cet. II; Yogyakarta: Absolut, 2004), hal.

${ }^{4}$ Masnur Muslich, Pendidikan Karakter Menjawab Tantangna Krisis Multidimensional (Jakarta: Bumi Aksara, 2011), hal. 70. 
Sementara itu, karakter sama dengan kepribadian. Kepribadian dianggap sebagai ciri atau karakteristik atau gaya atau sifat khas dari seseorang yang bersumber dari bentukan-bentukan yang diterima dari lingkungannya, misalnya keluarga, masyarakat, atau bisa pula merupakan bawaan yang dibawa sejak lahir itu sebagaimana yang dikatakan koesuma ${ }^{5}$. Selanjutnya pendidikan karakter merupakan suatu pengaturan penanaman nilai-nilai karakter kepada individu sekolah yang menambahkan kepercayaan, kewaspadaan, dan kesiapan serta kegiatan untuk melakukan sifat-sifat terbaik kepada Tuhan yang Maha Esa, diri sendiri dan lingkungan sekitar, sehingga manjedi manusia yang insanul kamil. ${ }^{6}$

Hal tersebut di atas, dapat dipahami bahwa karakter identik dengan akhlak,sehingga karakter merupakan nilai-nilai perilaku manusia yang universal dan meliputi seluruhaktivitas manusia, baik dalam rangka berhubungan dengan Allah atau Tuhannya, dengan dirinya, dengan sesama manusia, maupun dengan lingkungannya, yang terwujud dalam pikiran, sikap, perasaan, perkataan, dan perbuatan berdasarkan norma-norma agama, hukum, tata krama,budaya, dan adat istiadat. Adapun pengertian karakter menurut para ahli adalah sebagai berikut:

1) Karakter sebagai atribut atau ciri-ciri yang membentuk dan membedakan ciri pribadi, ciri etis, dan kompleksitas mental dari seseorang, suatu kelompok atau bangsa. Menurut Scerenco ${ }^{7}$ hal ini juga dikatakan oleh Herman kertajaya mengemukakan bahwa "karakter adalah ciri khas yang dimiliki seseorang dan ciri khas tersebut adalah asli mengakar pada kepribadian seseorang tersebut dan merupakan mesin pendorong bagaimana sesorang bertindak, bersikap, berujar,dan merespon sesuatu". 8

2) Winnie memahami dua pengartian tentang karakter satu, ia menunjukkan cara seseorang berprilaku tidak jujur, kejam atau rakus, tentulah seseorang orang tersebut memanifestasikan prilaku buruk. Sebaliknya apabila sesorang berprilaku buruk. Sebaliknya, apabila seseorang berprilaku jujur, suka menolong, tentulah orang tersebut memanifestasikan karakter mulia. Berarti makna tersebut menunjukkan bahwa karakter merupakan perbuatan yang dilakukan secara sadar dan merupakan kebiasaan seseorang itu. Dua karakter itu erat kaitanya

5Doni Koesuma A, Pendidikan Karakter Strategi Mendidik Anak di Zaman Global (Jakarta: Grasindo: 2010), hal. 80.

6 Muhammad Ihsan Karmedi, dkk, Pendidikan Karakter dalam Pembelajaran Sejarah Selama Pandeni Cocid 19, jornal of education research, 2 (1), 2021, page 44-46

7 Muclas samani \& Hariyanto, pendidikan karakter konsep dan model, (Bandung;Alfabeta,2012), hal.2

8Jamal Mae'mur Asmani, Buku panduan internalisas ipendidikan karakter disekolah.(yogyakarta:Diva press,2012),hal.28 
dengan personality. Seseorang baru bisa disebut orang yang berkarakter apabila tingkah lakunya sesuai dengan kaidah moral. ${ }^{9}$

Maka dari pengertian di atas kualitas atau moral, akhlak, atau budi pekerti individu yang merupakan kepribadian khusus, yang menjadi pendorong dan penggerak, serta membedakanya dengan individu lain merupakan karakrter. Anak dapat dikatakan berkarakter, jika telah berhasil menyerap nilai dan keyakinan yang dikehendaki masyarakat, baik buruk itu masyarakat yang menentukan, selanjutnya digunakan sebagai moral dalam hidupnya.Setelah mengetahui tentang pengertian dari "pendidikan" dan "karakter", maka peneliti akan menguraikan tentang pengertian pendidikan karakter, pendidikan karakter sebagai bentuk upaya sadar dan sungguhsungguh dari seorang guru untuk mengerjakan nilai-nilai kepada para sisiwanya. ${ }^{10}$

Pendidikan karakter merupakan sebuah usaha untuk mendidik anakanak agar dapat mengambil keputusan dengan bijak dan mempraktikanya dalam kehidupan sehari-hari, sehingga mereka dapat memberikan kontribusi yang positif kepada lingkunganya, hal ini sebahaimana dikemukakan oleh Ratna Mawangi. ${ }^{11}$ Thomas Lickona mengatakan pendidikan untuk membentuk kepribadian seseorang melalui pendidikan budi pekerti, yang hasilnya terlihat dalam tindakan nyata seseorang, yaitu: tingkah laku yang baik, jujur, bertanggung jawab, menghormati hak orang lain, kerja keras dan sebagainya ${ }^{12}$

Selanjutnya pendidikan karakter dapat dimaknai sebagai upaya yang sungguh-sungguh dengan cara mana ciri kepribadian positif dikembangkan, didorong dan diberdayakan melalui keteladanan, kajian (sejarah dan biografi pra bijak dan pemikir besar), serta praktik emulasi (usaha yang maksimal untuk mewujudkan hikmah dari apa-apa yang dipelajari). ${ }^{13}$ Pendidikan karakter dalam konteks pendidikan di negara ini merupakan pendidikan nilai dimana pendidikan nilai-nilai luhur yang bersumber dari budaya bangsa Indonesia sendiri, dalam rangka membina kepribadian generasi selanjunya.

\section{Macam- macam karakter}

Ada 18 nilai karakter yang akan ditanamkan pada diri peserta didik sebagai upaya membangun membangun karakter bangsa. Nilai-nilai karakter

\footnotetext{
9HeriGunawan, pendidikan karakter konsep dan Implementasi, (Bandung:Alfabeta,2012), hal.2

10Muchlas Samani \& Harianto, pendidikan karakter konsep dan model,(Bandung:PT Remaja Rosdakarya,2011),hal.45 hal.23

11Dharma kusuma,pendidikan karakter kajian teori dan praktik di sekolah, (Bandung :PT Remaja Rosdakarya,2011),hal.5

12 Heri Gunawan, pendidikan karakter konsep dan Implementasi, (Bandung: Alfabeta ,2012),
}

13 Muclas Samani\&Hariyanto,pendidikan karakter, hal.45 
rumusan Kementerian Pendidikan Nasional tersebut selengkapnya adalah sebagai berikut: ${ }^{14}$

1) Religius, merupakan sebuah ketaatan dan kepatuhan dalam memahami dan melaksanakan ajaran agama (aliran kepercayaan) yang dianut, termasuk dalam hal ini adalah sikap toleran terhadap pelaksanaan ibadah agama (aliran kepercayaan) lain, serta hidup rukun dan berdampingan.

2) Sikap dan perilaku yang mencerminkan kesatuan antara pengetahuan, perkataan dan perbuatan (mengetahui apa yang benar, mengatakan yang benar dan melakukan yang benar) sehingga menjadikan orang yang bersangkutan sebagai pribadi yang dapat dipercayahal ini merupakan nilai karakter jujur.

3) Toleransi, merupakan sikap dan perilaku yang mencerminkan penghargaan terhadap perbedaan agama, aliran kepercayaan, suku, adat, bahasa, ras, etnis, pendapat, dan hal-hal lain yang berbeda dengan dirinya secara sadar dan terbuka, serta dapat hidup tenang di tengah perbedaan tersebut.

4) Kebiasaan serta tindakan yang konsisten terhadap segala bentuk peraturan atau tata tertib yang berlaku merupakan nilai karakter kedisiplinan.

5) Kerja keras, merupakan perilaku yang kesungguhan dalam berjuang hingga titik darah penghabisan dalam menyelesaikan berbagai tugas, permasalahan, pekerjaan, dan lain-lain dengan sebaik-baiknya.

6) Kreatif, yakni sikap dan perilaku yang mencerminkan inovasi dalam berbagai segi dalam memecahkan masalah, sehingga selalu menemukan cara-cara baru, bahkan hasil-hasil baru yang lebih baik dari sebelumnya.

7) Mandiri, yakni sikap dan perilaku yang tidak tergantung pada orang lain dalam menyelesaikan berbagai tugas maupun persoalan. Namun hal ini bukan berarti tidak boleh bekerja sama secara kolaboratif, melainkan tidak boleh melemparkan tugas dan tanggung jawab kepada orang lain.

8) Demokratis, yakni sikap dan cara berpikir yang mencerminkan persamaan hak dan kewajiban secara adil dan merata antara dirinya dengan orang lain.

9) Rasa ingin tahu, yakni cara berpikir, sikap, dan perilaku yang mencerminkan penasaran dan keingintahuan terhadap segala hal yang dilihat, didengar, dan dipelajari secara lebih mendalam.

10) Semangat kebangsaan atau nasionalisme, yakni sikap dan tindakan yang menempatkan kepentingan bangsa dan negara di atas kepentingan pribadi atau individu dan golongan.

14 Kemendiknas, Panduan Pendidikan Karakter, Jakarta: Pusat Kurikulum dan Kebukuan Kemendiknas, (2011), hal. 2 
11) Cinta tanah air, yakni sikap dan perilaku yang mencerminkan rasa bangga, setia, peduli, dan penghargaan yang tinggi terhadap bahasa, budaya, ekonomi, politik, dan sebagainya, sehingga tidak mudah menerima tawaran bangsa lain yang dapat merugikan bangsa sendiri.

12) Menghargai prestasi, yakni sikap terbuka terhadap prestasi orang lain dan mengakui kekurangan diri sendiri tanpa mengurangi semangat berprestasi yang lebih tinggi.

13) Komunikatif, senang bersahabat atau proaktif, yakni sikap dan tindakan terbuka terhadap orang lain melalui komunikasi yang santun sehingga tercipta kerja sama secara kolaboratif dengan baik.

14) Cinta damai, yakni sikap dan perilaku yang mencerminkan suasana damai, aman, tenang, dan nyaman atas kehadiran dirinya dalam komunitas atau masyarakat tertentu.

15) Gemar membaca, yakni kebiasaan dengan tanpa paksaan untuk menyediakan waktu secara khusus guna membaca berbagai informasi, baik buku, jurnal, majalah, koran, dan sebagainya, sehingga menimbulkan kebijakan bagi dirinya.

16) Peduli lingkungan, yakni sikap dan tindakan yang selalu berupaya menjaga dan melestarikan lingkungan sekitar.

17) Peduli sosial, yakni sikap dan perbuatan yang mencerminkan kepedulian terhadap orang lain maupun masyarakat yang membutuhkannya.

18) Tanggung jawab, yakni sikap dan perilaku seseorang dalam melaksanakan tugas dan kewajibannya, baik yang berkaitan dengan diri sendiri, sosial, masyarakat, bangsa, negara, maupun agama.

\section{Penanaman Karakter Religius}

Penanaman karakter religius atau agama Islam di lingkungan Sekolah

Dasar Islam Terpadu Semarak, secara lebih terperinci dapat dilaksanakan melalui metode/cara sebagai berikut. ${ }^{15}$

1) Pembiasaan. Hal ini bisa dilakukan dengan membiasakan anak-anak membaca atau mengucapkan (dengan menyadari artinya) seperti mengucapkan basmalah sebelum memulai suatu perbuatan. Membaca hamdalah sebagai ucapan syukur atas segala hasil yang diterima.

2) Latihan (demonstrasi). Anak dibiasakan untuk melakukan latihan, seperti mengadakan praktek mengerjakan sholat, berwudhu, tayamum, adzan iqomat dan lain-lain.

3) Praktek lapangan. Mengajak anak untuk membantu melakukan pekerjaan yang berhubungan dengan lingkungan masyarakat. Seperti

15Adisusilo, Sutarjo. 2012. Pembelajaran Nilai - Karakter: Konstruktivis medanVCT Sebagai Inovasi Pendekatan Pembelajaran Afektif.Jakarta: PT Raja Grafindo Persada 
kerja bakti, membersihkan tempat-tempat ibadah (mushola, masjid) dan lain-lain.

4) Kompetesi. Menyuruh anak-anak mengikuti perlombaan yang dalam menyongsong perayaan hari-hari besar Islam atau nasional seperti perlombaan pidato, adzan, mengarang, melukis dan lain-lain.

5). Pengembangan bakat. Pengembangan bakat anak dapat dilakukan dengan berbnagai cara, diantaranya dalam bidang seni suara anak dapat diajarkan nyanyian/lagu yang berjiwa agama seperti lagu maulid nabi, isra miraj. Dalam bidang seni kaligrafi seperti kaligrafi arab.

6). Teladan. Keteladanan dalam pendidikan merupakan metode yang berpengaruh dan terbukti paling berhasil dalam mempersiapkan dan membentuk aspek moral, spiritual,dan etos sosial anak. Teladan yang baik perlu di perlihatkan orang tua dalam mendidik anak-anaknya, karena anak-anak biasanya suka mengedintifikasi diri kepada orang tua yang diajadikan sebagai figure yang dicintai.

7). Perintah dan larangan. Contoh perintah ini dapat berupa menyuruh anak mengerjakan ibadah dan berahlak dengan ahlak terpuji.Adapun contoh larangan dapat berupa melarang anak melakukan tingkah laku yang tercela.

8). Ganjaran dan hukuman. Ganjaran dalam pendidikan Islam diperlukan untuk membiasakan anak-anak agar melaksanakan kebaikan dan menghindarkan diri dari kemungkaran. Adapun metode hukuman dapat pula dilaksanakan dalam pendidikan Islam, selama tidak ada cara untuk memperbaiki kesalahan, tetapi harus digunakan dengan sangat hati-hati.

\section{Nilai Karakter Religius}

Religius sebagai salah satu nilai dalam pendidikan karakter dideskripsikan oleh Kemendiknas, sebagai sikap dan prilaku yang patuh dalam melaksanakan ajaran agama yang dianut, toleransi terhadap pelaksanaan ajaran agama yang dianut, toleransi terhadap ibadah agama lain, dan hidup rukun pada pemeluk agama lain. Selanjutnya Ngainun Naim mengungkapkan bahwa nilai religius merupakan penghayatan dan implementasi dari ajaran agama dalam kehidupan sehari-hari. ${ }^{16}$

Kementerian Pendidikan Nasional telah merumuskan 18 nilai karakter yang akan ditanamkan pada diri peserta didik sebagai upaya membangun membangun karakter bangsa. Nilai-nilai karakter rumusan Kementerian Pendidikan Nasional tersebut selengkapnya adalah sebagai berikut: ${ }^{17}$ Religius, yakni ketaatan dan kepatuhan dalam memahami dan

16 Rizal Abdurrahman,dkk, Implementasi Pendidikan Karakter Religius di SMP Negeri 5 Purbalingga, Alhamra: Jurnal Studi Islam: Volume 1 No. 2 Agustus 2020: 140

17 Kemendiknas, Panduan Pendidikan Karakter, Jakarta: Pusat Kurikulum dan Kebukuan Kemendiknas, (2011), hal. 2 
melaksanakan ajaran agama (aliran kepercayaan) yang dianut, termasuk dalam hal ini adalah sikap toleranterhadap pelaksanaan ibadah agama (aliran kepercayaan) lain, serta hidup rukun dan berdampingan.

Dalam proses pembinaan nilai-nilai agama atau karakter religius anak yakni untuk membentuk kepribadiannya dapat dimulai sejak lahir sampai dewasa. Pada intinya Pendidikan Agama Islam dalam keluarga itu mencakup tiga hal yaitu: pendidikan akidah/keimanan contohnya ketika lahir anak diperkenalkan dengan kalimat thoyyibah, kemudian setelah mereka tumbuh dan berkembang menjadi anak-anak ditanamkan nilai-nilai agama yang berkaitan dengan keimanan, sehingga anak meyakini adanya Allah dan dapat meyakini Allah dengan seyakin-yakinya (ma'rifatullab). Pendidikan ibadah contohnya ketika anak berusia tujuh tahun diperintah sholat, puasa dan lainlain dan pendidikan ahlakul karimah contohnya anak ditanamkan sifat-sifat yang baik seperti kejujuran, keadilan, sabar dan lain-lain dibimbing mengenai nilai-nilai moral seperti cara bertutur yang baik, berpakai yang baik, bergaul dengan baik dan lain-lain. Dengan adanya pendidikan tersebut pada anak di lingkungan keluarga itu akan membentuk kepribadian yang baik bagi anak yaitu menjadi manusia yang beriman, bertakwa dan berahlakul karimah, meiliki hubungan yang baik pada allah (bablumminallab) dan memiliki hubungan yang baik dengan manusia (bablumminannas).

Selanjutnya cara guru menyampaikan nilai karakter religius pada anak tersebut tidak selalu melalui cerita menggunakan bahasa daerah atau indonesia akan tetapi lebih banyak kepada pembiasaan, misalnya sebelum masuk ruangan salam, cium tangan dan shalat dhuha, selanjutnya ketika belajar agama menggunakan media pembelajaran berupa gambar atau sesuatu yang menunjukkan karakter religiusnya.

Hal ini sebagaimana dikatakan dari wawancara dengan guru yang mengatakan bahwa: "kegiatan di sekolah masuk 07.10 siswa mengaji dibimbing oleh guru kelas dan dilanjutkan dengan shlat dhuha, selanjutnya 08.00-12.00 kegiatan belajar mengaran dan setelah 12.00-13.00 persiapan shalat dhuhur dan kemudian shalat duhur berjamaan". ${ }^{18}$ Hal ini senada seperti yang dikatakan oleh guru fiqih, yang mengatakan bahwa: jam 07.00 ketika anak-anak sudah tiba di Sekolah mereka langsung menuju ke Mushola untuk kegiatan mengaji sampai jam 07.30, setelah itu anak-anak wudhu dan segera melaksanakan shalat Sunnah dhuha samapi jam 07.50. ${ }^{19}$

Selanjutnya menurut wali kelas juga menjelaskan bahwa "guru piket pagi-pagi menyambut kedatangan anak-anak dengan salam, cium tangan guru". ${ }^{20}$ Dari hasil wawancara tersebut itu, maka sangat menjadi penting penanaman nili-nilai karakter dengan bahasa anak-anak dan pembiasaan

18 Wawancara dengan zaelansyah (guru al-qur'an)

19 Wawancara dengan Elis Sandrawita. S.Pd (guru fiqih)

20 Wawancara dengan Fitri. (Wali kelas 2) 
setiap hari. Sehingga dapat mendorong peserta didik untuk melakukannya dapat melakukan setiap hari. Cara kedua ialah pengimplementasian melalui budaya sekolah. Budaya sekolah sendiri dibagi menjadi empat cara, antara lain: (1) pertama, melalui kegiatan rutin setiap hari pada pukul 07.15- 07.30. Melakukan tadarus Al-Qur,an yang sudah menjadi brandednya sekolah Islam terpadu setiap pagi. Hal ini sebagaimana dalam bentuk program sekolah dibawah ini: ${ }^{21}$
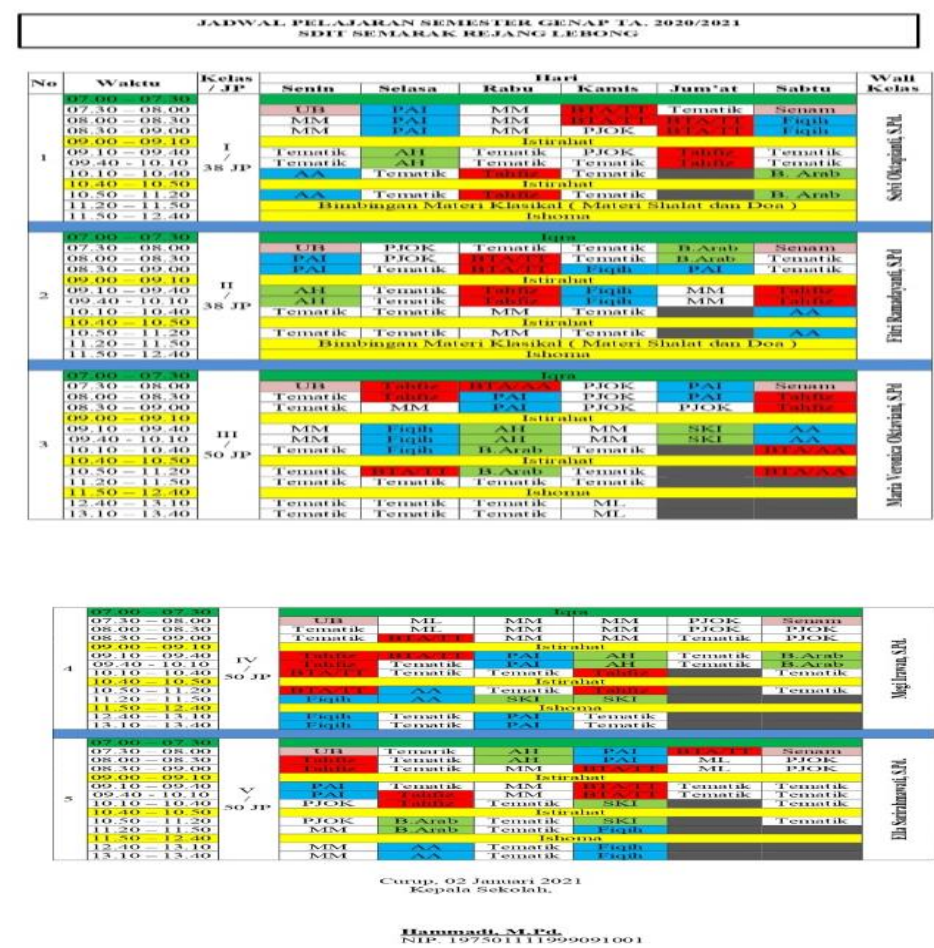

Dari jadwal kegitan di atas, maka program yang dilakukan sudah terstruktur oleh karena itu, penanaman nilai-nilai karakter melalui kegiatan rutin. Antara lain yang berkaitan dengan nilai- nilai agama, disiplin, mandiri, bersahabat/komunikatif, dan lain-lain. Proses ini dilakukan melalui pembiasaan dan kadang guru menyampaikan pesan moral secara langsung dari kegiatan yang dilakukan. Sedangkan kegiatan senam bersama dilakukan di sekolah dimaksudkan untuk mendukung penanaman nilai-nilai karakter pada peserta didik. Selanjutnya dengan mengimplementasikan pendidikan karakter religius tersebut dalam kehidupan sehari-hari. Dengan menanamkan pendidikan karakter religius melalui pembiasaan akan menjadikan bermakna dan membekas dalam diri peserta didik. 


\section{KESIMPULAN}

Penanaman pendidikan karakter religious melalui metode pembiasaan di SD IT Semarak Rejang lebong dilakukan dengan cara pembiasaan setiap hari dengan nilai-nilai religius seperti pertama: dengan membiasakan shalat Sunnah dhuha, kedua: murojaah/ tadarus Al-Qur'an/ menyambung ayat-ayat pendek, ketiga melaksanakan shalat dhuhur secara berjamaah.

\section{BIBLIOGRAFY}

Abdurrahman, Rizal, dkk, Implementasi Pendidikan Karakter Religius di SMP Negeri 5 Purbalingga, Alhamra: Jurnal Studi Islam: Volume 1 No. 2 Agustus 2020

Asmani, Jamal Maemur, Buku panduan internalisas ipendidikan karakter disekolah. Yogyakarta:Diva press,2012.

Gunawan, Heri, pendidikan karakter konsep dan Implementasi, Bandung:Alfabeta,2012.

Hariyanto, Muclas samani, pendidikan karakter konsep dan model, Bandung;Alfabeta,201

Karmedi, Muhammad Ihsan, dkk, Pendidikan Karakter dalam Pembelajaran Sejarah Selama Pandeni Cocid 19, journal of education research, 2 (1), 2021

Kemendiknas, Panduan Pendidikan Karakter, Jakarta: Pusat Kurikulum dan Kebukuan Kemendiknas, 2011

Koesuma , Doni A, Pendidikan Karakter Strategi Mendidik Anak di Zaman Global, Jakarta: Grasindo: 2010.

Kusuma, Dharma, ,pendidikan karakter kajian teori dan praktik di sekolah, Bandung :PT Remaja Rosdakarya,2011.

Lena, Nelson, Siswanto, Implementasi Nilai-Nilai Karater Menurut Kearifan Lokal Masyarakat Lembak, Kecamatan Binduriang, Paramurabbi: Jurnal Pendidikan Islam, ojs.unsiq.ac.id/index.php/paramurobi/article/view/ Maulana, Achmad dkk, Kamus Ilmiah Populer, Cet. II; Yogyakarta: Absolut, 2004 Muslich, Masnur ,Pendidikan Karakter Menjawab Tantangna Krisis Multidimensional, Jakarta: Bumi Aksara, 2011

Sutarjo, Adisusilo, Pembelajaran Nilai - Karakter: Konstruktivis medanVCT Sebagai Inovasi Pendekatan Pembelajaran Afektif.Jakarta: PT Raja Grafindo Persada, 2012 